\title{
Categories of Multicultural Dialogue from the Point of View of Contemporary Communication
}

\author{
Prof. Dr hab. Bogdan Zeler
}

University of Silesia in Katowice, Poland

Email: bogdanzeler@gazeta.pl

Doi:10.5901/ajis.2013.v2n8p88

\section{Abstract}

The perspective of intercultural dialogue seems to be extremely important, especially nowadays, for reflection on culture communication. The paper concerns the changes appearing in understanding of such terms as the Same, the Other, the Different, the Second-which constitute thinking on intercultural communication. It seems that the starting point of the discussion should become the perspective outlined by the outstanding Polish writer Ryszard Kapuściński in the volume of his essays "This Other". The proposition of the interpretation described in the paper is on one hand connected with the perspective of the philosophy of dialogue, especially with the reflection of Emanuel Levinas and of Polish philosopher and priest Józef Tischner, and on the other-with transformations of intercultural dialogue implicated by new media, especially by the networked perspective of Internet. The paper describes reevaluations appearing on the Internet and concerning categories important for this kind of communication. The Network emerges as the place of opening for "the Second" and simultaneously as the space of rejection and exclusion. The analysis of the phenomenon of inter culturally leads to the conclusion that the so-far understanding of categories constituting the intercultural discourse needs to undergo the fundamental transformations and reevaluations. On the place of so-far oppositions there appear new ones, formed i.e. by new technologies. One of them may be the necessity of dialogue between "young" and "old", where only the first group seems to be completely competent participants of networked life, when the second group become "the Others" of cyber-world.

Keywords: dialogue, multicultural, us, them, different, the other

Conceição Lima, a poet of São Tomé e Príncipe, a former Portuguese colony, is the author of the following words which seem to define the original order of the world, in which everything was a unity and people appeared as a community:

The old man raised the child with its face to the east

"all your fathers"

And he slowly raised it with its face westward:

"all your mothers"

This world of "the earliest beginnings" is nothing but a memory now. The truth about the present-day world seems to be rendered better in a poem by a Mozambican poet rooted in Portugal Rui Knopfli, a poem titled "Authority", in which he refers to his family roots, Mozambican and Portuguese, but also the roots reaching, so to say, the world of sedate Central European culture:

Of Portuguese things I have nostalgia

For what passes [...]

Arabic flame in my eyes [...]

Of Swiss things, I have an old pocket watch

Inherited from my great-grandfather, and a rare, weird surname.

Eugénio Lisboa, the eminent literacy critic, comments on Knopfli's poetry with the following words: „The African and culturally but not geographically deeply European Mozambique has always been a place where the spiritual horizon becomes complete - due to Europe (Viegas, 2008, pp. 95-96).

The attitude of one man to another oscillates unceasingly among a few paradigms of behavior. Let me outline these patterns.

The first one is closely related to the fourth thesis of Lessing's The Education of the Human Race which reads: "Education gives to Man nothing which he might not reduce out of himself; it gives him that which he might reduce out of 
himself, only quicker and more easily." This leads to the assumption that another man cannot shape our humanity and that everything can be achieved thanks to us ourselves. This attitude is marked then by distance from other people.

The second model is related to the notion of the Other. According to this model human understanding can come across insurmountable obstacles. The Other has a different language, culture and a place to live. "In modern times cultures, languages, customs and traditions alien to the victorious civilization perish on a grand scale. What is left (market, television, Internet) is well-known to anybody and as such it cannot be seen as a challenge from beyond the system. Globalization consists in the predominance of one system and a frantic attempt to tame the Other within the system. What is excluded by the system has no reason for existence".(Czerniak, 2002, pp. XXVI - XXVII). This makes us realize how much the notion of the Other has dominated our perception of another man in the world.

The third way assumes that coexistence should be understood as dialogue. As Barth says "there is no humanity in loneliness" (Barth, 2002, p. 193) and adds a comment on the meaning of "I" juxtaposed with "You": "What does 'I' mean? I say this word and by this I make a distinction and establish a relation. [...] By this word I distinguish myself from another man, who is not me but is not just "it", an object, but is someone who may assess and understand my announcing myself as "l", because he can announce himself to me in the very same way". By distinguishing the other man from myself I assume, accept and establish - if it depends on me - a relation with him: with him as a one like me. By addressing this object as "I" I distinguish it not only from myself but also from all other objects, from every "it"; I put it with me myself [...] in the same space I am not without him, my space is not only mine, but also his" (Barth, 2002, p. 135)

Also one of the outstanding philosophers of the $20^{\text {th }}$ century Emmanuel Levinas, for whom the primary category was another man , the face of the Other, says: "The phenomenon of the Other manifesting himself, is face [...] The epiphany of face is visitation [...] The phenomenon of face is the primeval speech. Speaking is first of all a way of coming out from beyond a phenomenon, its form, an opening to opening" (Levinas,1991 , p. 107).

While discussing the issue of dialogue with another man, it is necessary to refer to the views held by a great Polish philosopher the Reverend Józef Tischner and his notion of "the philosophy of drama". He stresses the importance of the unique experience of encountering another person. This experience is a kind of conclusive experience, ranking first in the scale of human fate. Actually, what is meant is the understanding of another man whatever differences there are between us. Tischner writes that "Earlier the love for one's neighbor manifested itself in the commandment you shall not kill your enemies. You must understand, because your enemy has much to tell you about you yourself, about your condition" (Tischner, 1994, p. 64). So the dialogue with another man, the understanding of another man in both senses of the word, can become a source of self-comprehension, can offer us a chance of defining ourselves in the world, can be an answer to the question about the sense of life. The intercultural dialogue perspective seems to be particularly important in the reflection upon cultural communication.

Ryszard Kapuściński, an outstanding Polish publicist, repeatedly drew attention to the issue of intercultural dialogue in the countries of postcolonial Africa and Ibero-America, of which most noteworthy were the essays in the collection The Soccer War (1978) (Kapuściński, 2008, p. 72). Analyzing the culture of Ibero-America he says: „This is a continent where you can notice cooperation between cultures, races and religions. It is a kind of syncretism, in which Catholicism mingles with ancient beliefs. And what most interesting and absolutely exceptional, there is no aggressive nationalism here. One can wander over whole Latin America and he will not find a single symptom of hatred or rejection. It can serve a good model for the twentieth first century" (Kapuściński, 2007, p. 102). In Kapuściński's opinion there will arise a new hybrid culture, which unites various elements of Amerindian, African and European cultures. It will involve a reorientation of the understanding of the term "nation", which should be then understood as the multiethnic and multicultural community.

José Garza, a Mexican writer and journalist, commented upon these words of Kapuścinski on the importance of transformations taking place in the countries of Latin America: "Kapuściński solved the mystery of Latin America; he discovered how the brusqueness resulting from the cultural variety of the continent, penetrates all spheres of the local life" (Garza, 2008, p. 198). This Mexican critic of Kapuściński's work stresses also the fact that Kapuściński's ideas are implanted extremely strongly in the search for truth about the Other, another person who ceases to be alien and becomes One of Us, implanted in the culture common to us all. "Kapuściński understood that every person whom he met on his way, the one spreading a Persian carpet and the one watching the sunrise in African desolation - desires freedom to be able to express himself; and that the spreading of the carpet and the watching of the sunrise expresses the hope of thousands of people forced to abandon their homeland to survive and look for a better life or simply for their own place on earth" (Garza, 2008, p. 196).

Among Kapuściński's works we can find a book about the problem in question, that is, human dialogue. The book is titled "Ten Inny /The Other" (Kapuściński, 2006, pp. 51-63) Kapuściński analyzes in it the on-going anthropological 
breakthrough, the philosophy of dialogue and the breakthrough of multiculturalism. A special place is reserved there for Emanuel Lévinas, who insisted that the difference, the otherness of the Other is a good that we experience when we encounter him.

The writer draws our attention to the changes in the understanding of the notions of "One of Us", "One of Them", The Other, The Different in the era of globalization. The revolution in communication brings the contemporary man dozens of cultures, as meaningful as his own national culture. As Kapuscinski says: " Once Marshall McLuhan said that the Word Gould become a global village but today we can say that there will be space for a global world in each of those villages" (Kapusciński, 2001, p. 102).

The traditional understanding of the categories constituting intercultural dialogue must undergo radical transformation and revaluation. The network society coming into existence in the days of the internet becomes a community of all network users, yet there can be observed the phenomenon of alienation from the community. This alienation can take different forms, as the basic issue is the issue of availability of the medium. Still, especially in the Third World countries, this availability is purely illusive. In this way technology generates the division into Us and Them. Another cause of this alienation stems from the division into generations, hampering the dialogue between the young and the old, of whom only the former seem to be competent participants in the network life whereas the latter become the Aliens in the digital world.

The intercultural dialogue is the foundation of cultural identity, which can be defined two ways First, identity can be regarded as a historically shaped collective self. The other approach assumes that among a number of similarities, there can be observed significant and meaningful differences, which determine who we really are" (Fanon, 1985, p. 149).

A characteristic feature of the traditional identity was its constancy. It was place- and tradition-bound. Now the sense of continuity has become replaced with the momentariness determined by logging in and by a peculiar "suspension" of reality.

So what future is ahead of us? Will the category of national identity fade into oblivion? Authentic culture cannot be thought of in a different way than as a phenomenon based on individualized spiritual consciousness. Dispersed over a wide area, it rarely stays physically fit and subtle [...] By contrast, a general international culture is difficult to imagine [...] Culture will have to unite with relatively small social and political entities, which thanks to their size will be able to give room to the individual and to what for culture is like water for a fish" (Whorf, 1982, p. 251). This idea of Whorf's is well matched by an opinion expressed from quite a different standpoint by Zygmunt Baumann, who writes that: „The global certainty, justified or not, broke into pieces, but crumbling it broke into pieces of tiny local certainties, to which one clings even stronger the weaker they are and the more care they need to remain certainties" (Bauman, 1995, p. 325).

Perhaps we will see the growing role of „little homelands", the places we are associated with at a given moment. Powerful evidence is provided, for example, by contemporary Polish noel set in local societies of Galicia, Lake District, Silesia and Gdansk. Perhaps the tale of "little homelands" will be taken over by the community of internet discussion groups.

Or perhaps it is Jacques Attali who is right, when in the entry "identity" in The $21^{\text {st }}$ century Dictionary" he writes: "Everyone will aspire to be unique [...] to have his or her own life, past, name, another identity and to continuous change through participation in the general carnival. Everyone will try to live in different ways, to take up different professions and belong to different families - simultaneously" (Attali, 2002, p. 223).

\section{References}

Attali J. (2002) Słownik XXI wieku Warszawa

Barth K. (2002) Podstawowa funkcja człowieczeństwo in ed. Baran B. Filozofia dialogu Warszawa

Bauman Z. (1995) Etyka ponowoczesna Warszawa

Czerniak S. (2002) Założenia historyczne aplikacje Bernharda Waldenfelsa fenomenologii obcego, in Waldenfels B. Topografia obcego. Studia z fenomenologii obcego Warszawa

Fanon F. (1985) O kulturze narodowej, in Wyklęty lud ziemi Warszawa

Garza J. (2008), Czekaliśmy na książkę o Ameryce Łacińśkiej in R. Kapuściński Wojna futbolowa Warszawa

Kapuściński R. (2006) Ten inny Kraków

Kapuściński R. (2007) Rwący nurt historii, zapiski o XX i XXI wieku Kraków

Kapuściński R. (2008) Wojna futbolowa Warszawa

Levinas E. (2002) Ślad innego człowieczeństwo in ed. Baran B. Filozofia dialogu Warszawa

Tischner J. (1994) Tischner czyta katechizm Kraków

Viegas F.J. (2008) Dwie ojczyzny, ani jednej ojczyzny ( o wierszach Rui Knopfliego) Literatura na Świecie nr 1-2

Whorf B.L. (1982) Język, myśl, rzeczywistość Warszawa 